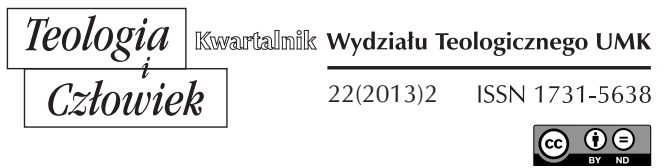

KS. KAZIMIERZ SKOCZYLAS*

TORUŃ-WŁOCŁAWEK

\title{
WARTOŚCI PRZEKAZYWANE NA KATECHEZIE KSZTAŁTUJĄCE SPOŁECZNE ZACHOWANIA
}

DOI: http://dx.doi.org/10.12775/TiCz.2013.021

Kościół, realizując swoją misję, kształtuje społeczne zaangażowanie wiernych. Dokonuje się to przez nauczanie jak i różne formy działalności duszpasterskiej. Zarówno wcześniejsze jak i obecne nauczanie Kościoła uwypukla znaczenie takiej aktywności ${ }^{1}$. Istotną w tym rolę odgrywa katecheza. Od czasów Soboru Watykańskiego II jesteśmy świadkami wielu rodzajów zaangażowania Kościoła w życie społeczne. Również ujawniające się problemy były okazją do podejmowania przez Kościół nauczania $\mathrm{w}$ tym zakresie. $\mathrm{W}$ ostatnim czasie wiele na ten temat wypowiadali się papież Jan Paweł II oraz papież Benedykt XVI.

\section{SPOŁECZNE NAUCZANIE KOŚCIOŁA NA PRZEŁOMIE XX I XXI WIEKU}

Wielką wartość dla kształtowania społecznych motywów zaangażowania wiernych miała Konstytucja Duszpasterska o Kościele Soboru

* Ks. dr hab. Kazimierz Skoczylas - prezbiter diecezji włocławskiej, adiunkt w Zakładzie Katechetyki i Pedagogiki Religii Wydziału Teologicznego UMK w Toruniu.

${ }^{1}$ Por. K. Skoczylas, Wychowanie społeczne w katechezie, w: Edukacja, kultura, teologia, red. K. Konecki, I. Werbiński, Torun 2003, s. 155-163 
Watykańskiego II. Uwypukla ona motywy społecznej aktywności wiernych. Mocno podkreśla, że każdy chrześcijanin powołany jest do uczestnictwa w rozwoju świata. Chrześcijanie obdarzeni darami Ducha Świętego powinni oddawać swe siły na służbę bliźnim. Są wezwani do pomnażania dobra wspólnego (por. KDK 33-41). W okresie posoborowym należy podkreślić nauczanie Pawła VI dochodzące do głosu w encyklice Populorum progresio. W ówczesnym kontekście rozwoju społeczno-gospodarczego akcentuje ona zasady w oparciu o które ten postęp powinien się dokonywać. Podkreśla on także, że rozwój nie jest celem samym w sobie, lecz ma służyć przede wszystkim rozwojowi człowieka (por. P. Prog. nr 19). Dzięki postępowi ma się rozwijać przede wszystkim sam człowiek².

W następnym etapie życia Kościoła wiele wniosło nauczanie Jana Pawła II, szczególnie jego encykliki społeczne (Laborem exercens, Solicitudo rei socialis, Centessimus annus). To nauczanie inspirowało cały Kościół. Pojawiły się nowe aspekty w tym nauczaniu. W konsekwencji Papieska Rada ds Sprawiedliwości i Pokoju w 2004 roku przygotowała Kompendium nauki społecznej Kościoła. Promulgacja tego kompendium została dokonana przez papieża Benedykta XVI i wiąże się z jego encykliką Caritas in veritate.

Kompendium nauki społecznej Kościoła uwypukla wartość osoby ludzkiej, podkreśla jej społeczną naturę, zwraca uwagę na przysługujące jej prawa. Na nowo zostaje tam podkreślone, że osoba ludzka jest otwarta na transcendencję i na wszystkie byty stworzone. Ona wykracza poza egoistyczne zachowania swojego życia, aby nawiązać relację dialogu i wspólnoty z drugim człowiekiem (por. KNSK 130). Człowiek w sposób wolny może zwrócić się ku dobru, które mu Bóg podarował (por. KNSK 135). Ludzką wolność ogranicza przeciwstawianie się prawu moralnemu. Przez takie zachowanie człowiek „przynosi szkodę własnej wolności, sam się zniewala, zrywa braterstwo z innymi ludźmi i buntuje się przeciw prawdzie Bożej" (KNSK 137). Wolność ludzką zabezpieczają prawa człowieka, które wynikają z natury ludzkiego bytu. Są one powszechne, niezbywalne i nienaruszalne (por. KNSK 153).

Osoba ludzka urzeczywistnia swoje człowieczeństwo tworząc dobro wspólne, które najogólniej jest rozumiane jako „suma tych warunków życia społecznego, które pozwalają bądź to grupom, bądź poszczególnym jego członkom pełniej i szybciej osiągnąć ich własną doskonałość" (KSNK 164). Wymaga ono zaangażowania na rzecz pokoju, organizacji

2 Tamże. 
władz państwowych, trwałego porządku prawnego, ochrony środowiska naturalnego, zabezpieczenia istotnych potrzeb człowieka, pożywienia, mieszkania, pracy, wykształcenia i dostępu do kultury, środków komunikacji, zdrowia, swobodnego przepływu informacji i ochrony wolności religijnej (por. KSNK 166). Kościół podkreśla, że każdy człowiek powinien mieć prawo do korzystania z dobrobytu, który pozwala mu osiągnąć doskonałość. Stąd mówi się o zasadzie powszechnego przeznaczenia dóbr ziemskich (por. KSNK 176).

Normie tej powinno być podporządkowane prawo własności. Tradycja chrześcijańska „zawsze rozumiała [prawo własności] [...] w najszerszym kontekście powszechnego prawa wszystkich do korzystania z dóbr całego stworzenia: prawo osobistego posiadania jako podporządkowane prawu powszechnego używania, uniwersalnemu przeznaczeniu dóbr" (KNSK 177). Zarazem zasada powszechnego przeznaczenia dobór wymaga szczególnego zainteresowania Kościoła osobami ubogimi i tymi, którzy znajdują się w sytuacji odrzucenia i marginalizacji. Oni powinni doświadczać pierwszeństwa w praktykowaniu miłości chrześcijańskiej. Podkreśla się $\mathrm{w}$ dokumencie, że obszar ubóstwa rozszerza się przyjmując zakres światowy. Stąd też domaga się to od Kościoła pierwszeństwa w praktykowaniu miłości na rzecz "głodujących, żebrzących, bezdomnych, pozbawionych pomocy lekarskiej, a nade wszystko nie mających nadziei na lepszą przyszłość" (KNSK 182).

W nauczaniu społecznym Kościoła mocno eksponuje się zasadę pomocniczości. Podkreśla się, że umożliwia ona wielkim grupom ludzi dobrej woli działanie na rzecz dobra wspólnego. Może ona pomniejszać negatywne skutki centralizacji, biurokracji, opiekuńczości, nieuprawnionej i przesadnej obecności państwa i władz publicznych w życiu społecznym. Daje to możliwość realizowania różnych form woluntariatu, który pozwala popierać godność osoby ludzkiej, troszczyć się o rodzinę i różne grupy społeczne. Zasada pomocniczości inspiruje do działania i zrzeszenia. Powstają instytucje o charakterze ekonomicznym, społecznym, kulturalnym, sportowym, rekreacyjnym, zawodowym, politycznym, które ludzie spontanicznie powołują do życia i które umożliwiają im społeczne wzrastanie (por. KNSK 185-187).

W życiu społecznym wielką rolę odgrywają wartości podstawowe. Do nich $\mathrm{w}$ porządku społecznym zalicza się prawdę, sprawiedliwość i wolność. „Ludzkie współżycie [...] przynosi owoce w postaci dobra i odpowiada godności człowieka, kiedy opiera się na prawdzie; przebiega 
według zasad sprawiedliwości, czyli z rzeczywistym poszanowaniem praw i uczciwym wypełnianiem odpowiadających im obowiązków; urzeczywistnia się w wolności, która odpowiada godności ludzi, pobudzanych przez swoją własną rozumną naturę do podejmowania odpowiedzialności za swoje działania; ożywiane jest przez miłość, która pozwala odczuwać potrzeby i wymogi innych, jako własne oraz powoduje, że wspólnota wartości duchowych i troska o potrzeby materialne są coraz mocniejsze" (KSNK 205). Stosunków międzyludzkich nie można układać jedynie zgodnie z miarą sprawiedliwości. Sprawiedliwość musi znaleźć dopełnienie w miłości (por. KNSK 206). Praktykowanie tych wartości jest drogą do udoskonalenia osoby i bardziej ludzkiego społecznego współistnienia (por. KNSK 197).

Kompendium eksponuje rodzinę wśród wartości służących człowiekowi. Stanowi ona centrum życia społecznego (por. KNSK 211). Podkreśla się tożsamość płciową człowieka w kontekście teorii uznających, że tożsamość męska czy żeńska jest tylko wytworem kultury i społeczeństwa (por. KNSK 224). Proces wychowania w rodzinie kształtuje człowieka. Ma on zatem wielką wartość. Jest on budowaniem dobra wspólnego. Stąd rodzina jest szczególnie ważna dla rozwoju każdej społeczności i jest też pierwszą szkołą życia społecznego. Ona odpowiada za wychowanie integralne. Takie wychowanie oznacza wychowywane do dialogu, spotkania, uczestnictwa w życiu społecznym, poszanowania prawa, solidarności i pokoju, przez kultywowanie fundamentalnych cnót sprawiedliwości i miłości (por. KNSK 241-242)

Dokument ten uwypukla także wartość pracy zarówno dla osoby jak i dla społeczeństwa. Przypomina, że ma ona wymiar podmiotowy, bowiem przez pracę człowiek urzeczywistnia swoje panowanie nad światem stworzonym. Stąd aspekt podmiotowy powinien górować nad przedmiotowym. Praca ma również wymiar społeczny. Praca jednego człowieka splata się zazwyczaj z pracą innych ludzi. Jest ona także obowiązkiem moralnym każdego człowieka. Ten obowiązek istnieje przede wszystkim wobec rodziny, następnie wobec społeczeństwa, do którego się należy oraz wobec narodu. Praca ma odniesienie do kapitału. Ona ten kapitał pomnaża, stąd właściwa relacji pracy wobec kapitału powinna się wyrażać $\mathrm{w}$ uczestnictwie pracowników we własności, w zarządzaniu nią oraz korzystaniu z jej owoców. Za solidnie wykonaną pracę należy się „słuszne wynagrodzenie”. Kto zaś go odmawia we właściwym czasie i w odpowiedniej proporcji do wykona- 
nej pracy lub zatrzymuje je, ten popełnia poważną niesprawiedliwość (por. KNSK 270-302).

Nauczanie kościelne skupia swoją uwagę także na warunkach dzięki, którym owoce pracy mogą być dystrybuowane. Uwypukla, więc znaczenie rynku i zasady prowadzenia handlu oraz wartość ekonomii i zasady, na których powinna ona się opierać. Wskazuje się na rolę państwa i organizacji międzynarodowych. Zwraca się uwagę na zjawisko globalizacji, które niesie ze sobą pozytywne i negatywne skutki. Dlatego troska o dobro wspólne wymaga wykorzystania nowych możliwości ponownego rozdziału bogactw pomiędzy różne regiony naszej planety na korzyść regionów do tej pory nieuprzywilejowanych lub będących na marginesie rozwoju społecznego i ekonomicznego (KNSK 363). „Globalizacja nie może być nową postacią kolonializmu. Musi respektować wielość kultur, które w ramach powszechnej harmonii narodów są jakby różnymi kluczami interpretacyjnymi ludzkiego życia. W szczególności zaś nie może odbierać ubogim tego, co pozostaje dla nich najcenniejsze, $\mathrm{w}$ tym ich wierzeń i praktyk religijnych, ponieważ autentyczne przekonania religijne są najbardziej wyrazistym przejawem ludzkiej wolności" (KNSK 366).

Wielką wartość przypisuje się w Komendium katechezie. Katechezy nie można ujmować w oderwaniu od działalności duszpasterskiej Kościoła. Zaś w tej działalności Kościół koncentrującej się wokół dzieła ewangelizacji. W takich okolicznościach trzeba mieć świadomość, że katecheza głoszenie nauki społecznej Kościoła musi uczynić jednym ze swych istotnych elementów (por. KNSK 523). W takim kontekście katecheza jest narzędziem formacji społecznej. $\mathrm{W}$ tej formacji powinna ona podejmować szczególnie ważne zagadnienia. Do nich należy: „działalność człowieka w celu integralnego wyzwolenia, poszukiwanie społeczeństwa bardziej solidarnego i braterskiego", a także „walka o sprawiedliwość i budowanie pokoju" (KNSK 529). Powinna ona starać się ukazywać całościowo nauczanie społeczne Kościoła odwołując się do jego historii, treści i metody. Wskazuje się, że powinno mieć miejsce wykorzystanie w tej katechezie treści encyklik społecznych. Jej zadaniem jest też budowanie w świadomości katechizowanych uzasadnień dla ewangelizacyjnej działalności Kościoła.

Drugim zakresem jej aktywności jest praca formacyjna. Celem tej formacji jest uzdolnienie ludzi do osądzania spraw doczesnych w świetle prawdy, rozwijanie zdolności planowania własnej aktywności 
w sposób odpowiedzialny, aby byli zdolni iść za tym, co prawdziwe i słuszne. Powinni też zdobyć zdolność współdziałania z innymi (por. KNSK 530). Jej efektem powinno być zaangażowanie społeczne. Stad też „świeccy - nie czekając biernie na nakazy i wskazówki skądinąd mają obowiązek przez śmiałe projekty i inicjatywy przepoić zmysłem chrześcijańskim nie tylko obyczaje i świadomość ludzi, ale również prawa i struktury społeczności świeckiej" (KNSK 531). Taka katecheza powinna „uzdolnić ich do skutecznego podejmowania codziennych zadań na polu kulturalnym, społecznym, ekonomicznym i politycznym, rozwinąć w nich poczucie obowiązku, wykorzystywane w służbie dla dobra wspólnego" (KNSK 531). Jej rolą jest także kształtować świadomość polityczną, aby przygotować wiernych świeckich do sprawowania władzy politycznej.

\section{NAUKA SPOŁECZNA KOŚCIOŁA W DOKUMENTACH KATECHETYCZNYCH}

Także dokumenty katechetyczne Kościoła powszechnego w dłuższej perspektywie czasu ujawniają świadomość konieczności podejmowania problematyki społecznej. Adhortacja Catechesi tradendae mówi o potrzebie ukazywania chrześcijańskiego sensu pracy ludzkiej, o kwestii dobra wspólnego, o problemie sprawiedliwości i miłości społecznej, o znaczeniu pokoju w stosunkach międzynarodowych, o godności osoby ludzkiej oraz o problemie wolności (por. CT 39). Także Dyrektorium Ogólne o Katechizacji zauważa potrzebę katechezy dla młodzieży i dorosłych podejmującej problematykę społeczną. Szczególne miejsce w niej należy przyznać zaangażowaniu chrześcijańskiemu w społeczeństwie (por. DOK 185). W katechezie dorosłych natomiast należy zwracać uwagę na wychowanie do właściwej oceny zmian społeczno-kulturalnych w świetle wiary. Taka katecheza powinna ułatwiać katechizowanym wybieranie prawdziwych wartości oraz uwrażliwiać ich na niebezpieczeństwa pojawiające się w cywilizacji. Zadaniem katechezy dla dorosłych jest też wyjaśniać istotne problemy życia publicznego i problematyki społecznej. (por. DOK 175)

Dokumenty katechetyczne Kościoła w Polsce również uwzględniają potrzebę podejmowania problematyki społecznej. Ta problematyka jest w Podstawie programowej katechezy Kościoła katolickiego w Polsce wydanej 
w roku $2001^{3}$ i $2010^{4}$. Obie Podstawy programowe katechezy przewidują na poziomie szkoły ponadgimnazjalnej zaznajomienie $\mathrm{z}$ tą problematyką. Podstawa programowa z roku 2001 nakazuje mówić o wydarzeniach z życia Kościoła, które ukazują go jako wspólnotę realizującą zasadę miłości. Szczególnie należy uwypuklić miłość przejawiającą się $\mathrm{w}$ trosce o cierpiących i niepełnosprawnych. Trzeba też mówić o uczestnictwie chrześcijanina $\mathrm{w}$ życiu społeczeństwa jako realizacji zasady służby. Winno się też ukazać zaangażowanie chrześcijanina na rzecz „małych ojczyzn” oraz uświadomić potrzebę uczestnictwa $\mathrm{w}$ kulturze ${ }^{5}$. Podstawa programowa katechezy z roku 2010 jest już bardziej precyzyjna w określeniu zakresu treści, które należy przekazać oraz umiejętności, które uczeń osiągnąć powinien po zapoznaniu z tymi treściami. Wymaga ona ukazania zasad życia w społeczeństwie. Należy więc ukazać pojęcie dobra wspólnego, różnice między patriotyzmem a nacjonalizmem oraz kosmopolityzmem. Należy też zaakcentować wartości wnoszone przez chrześcijaństwo w kulturę. Po zakończeniu procesu edukacji na tym poziomie uczeń powinien umieć scharakteryzować, na czym polega uczestnictwo chrześcijanina w życiu społecznym, jako realizacja zasady służby, powinien umieć przedstawić, że działalność polityczno społeczna chrześcijanina jest dążeniem do dobra wspólnego, umieć przewidzieć skutki braku poszanowania dla prawdy w życiu indywidualnym i społecznym, rozumieć znaczenie prawa własności dla życia społecznego oraz znać nauczanie Kościoła na temat wojny i pokoju ${ }^{6}$. Ta Podstawa programowa uwzględnia także odniesienie do treści nauczania „Wiedza o społeczeństwie”" Można więc powiedzieć, że na poziomie Podstawy programowej uwzględnia się nauczanie społeczne Kościoła i zasady, które formułuje Kompendium społecznej nauki Kościoła.

Również Ramowy Program Katechetyczny z $1971^{8}$ r. jak też Program Nauczania Religii z $2001^{9}$ roku oraz Program nauki religii z $2010^{10}$ roku

${ }^{3}$ Por. Podstawa programowa katechezy Kościoła katolickiego w Polsce, Kraków 2001.

${ }^{4}$ Por. Podstawa programowa katechezy Kościoła katolickiego w Polsce, Kraków 2010.

${ }^{5}$ Por. Podstawa programowa katechezy, (2001), s. 77-78.

${ }^{6}$ Por. Podstawa programowa katechezy, (2010), s. 77-78.

7 Tamże s. 94-95.

${ }^{8}$ Por. Ramowy program katechizacji w zakresie szkoty średniej (I - IV), w: Materiaty pomocnicze do nauczania religii. Szkoła średnia, Wrocław 1991, s. 15-17.

${ }^{9}$ Komisja Wychowania Katolickiego KEP, Program nauczania religii, Kraków 2001, s. $123-124$.

${ }^{10}$ Komisja Wychowania Katolickiego KEP, Program nauczania religii, Kraków 2010, s. 151-160 oraz 191-198. 
uwzględniają to zagadnienie. Trzeba dodać, że w Programie z roku 2010 przewidziano tę problematykę inaczej rozłożoną w układzie treści dla liceum i technikum. W liceum przewidziano ją w klasie drugiej, a $\mathrm{w}$ technikum $\mathrm{w}$ klasie trzeciej. Jest ona oddzielona od problematyki małżeństwa i rodziny, która przewidziana jest do realizacji w ostatniej klasie ponadgimnazjalnego cyklu kształcenia.

Program nauki religii z roku 2001 wymienia wśród zadań nauczyciela religii takie, które są realizacją społecznej nauki Kościoła. Mówi się tu o analizowaniu wydarzeń życia społeczno-politycznego w świetle Ewangelii, o uczeniu krytycznego spojrzenia na bieżące wydarzenia; o potrzebie dawania świadectwa wierze na różnych areopagach, aby pomóc uczniom zrozumieć przenikanie się religii i kultury; o wspieraniu uczniów w kształtowaniu hierarchii wartości opartej na społecznej nauce Kościoła ${ }^{11}$. Zatem zakres treści przewidziany do zrealizowania jest spełnieniem postulatu, aby katecheza miała charakter formacyjny, aby uczyła chrześcijańskiego zaangażowania w świecie. Nie ma tu natomiast takich treści, który by bezpośrednio przygotowywały do zaangażowania politycznego. Pośrednio natomiast, przez uczenie się oceny wydarzeń życia społeczno-politycznego kształtuje się umiejętności uczestnictwa w życiu politycznym rozumianym, jako rozumna troska o dobro wspólne.

Program z roku 2010 przewiduje podobne treści do realizacji w klasie II liceum jak ten z roku 2001. Uczeń powinien poznać zasady na podstawie których Kościół realizuję misję Chrystusa, zakres zaangażowania Kościoła w rozwiązywanie współczesnych problemów świata, podstawowe dokumenty przedstawiające katolicką naukę społeczną, powinien wiedzieć w czym wyraża się opcja na rzecz ubogich, znać pojęcie dobra wspólnego, patologie życia społecznego, stosunek Kościoła do kary śmierci, wojny i pokoju, obrony koniecznej, służby wojskowej, służby publicznej, praca i bezrobocie, stosunek pomiędzy patriotyzmem, nacjonalizmem i kosmopolityzmem, wierzący wobec polityki, problem zaangażowania politycznego wiernych świeckich ${ }^{12}$. Problematyka społeczna przewidziana jest w tym programem także w trzeciej klasie technikum. Szczególnie koncentruje się na tym blok programowy: „Ku nowym niebiosom i nowej ziemi"13. Zakres treści przewidzianej do realizacji w technikum niestety nie ujmuje tak wyraziście zagadnień przewidzianych przez Kompendium

11 Program nauczania religii, Kraków 2001, s. 123.

12 Program nauczania religii, Kraków 2010, s. 155.

13 Tamże, s. 195-196. 
społecznej nauki Kościoła jak w drugiej klasie liceum ogólnokształcącego. Zawarte są tam pewne odniesienia do treści wiedzy o społeczeństwie, która zawiera wiele elementów problematyki społecznej.

Program nauki religii jest podstawą do przygotowania treści podręczników katechetycznych i realizacji procesu dydaktycznego opartego na nich. Trzeba jednak zdawać sobie sprawę, że młodzież może poznawać ten zakres treści także poza katechezą. Jest to możliwe przez zapoznawanie się z tymi i podobnymi treściami w prasie, środkach masowego przekazu czy przez lekturę książek. Często ta problematyka jest przedmiotem nauczania Kościoła w Polsce dokonującego się przez listy pasterskie czytane w każdej parafii. Jej poglądy i przekonania kształtują również stowarzyszenia i organizacje oraz partie polityczne poprzez różne formy działania.

\section{STOSUNEK MŁODZIEŻY DO WARTOŚCI PODSTAWOWYCH}

Katolicka nauka społeczna podkreśla, że w życiu społecznym ważną rolę odgrywają wartości. Szczególny zakres tych wartości stanowią wartości podstawowe ważne dla społeczeństwa i państwa. Są one przedmiotem zainteresowania badaczy. W Polsce wartości podstawowe, jak twierdzi W. Piwowarski, pochodzą należą do porządku społecznego. One są podstawą jedności i porozumienia społecznego. W Polsce te wartości wywodzą się z trzech zasadniczych nurtów. Są to tradycja narodowa i historia, religia oraz nowsze ruchy społeczne ${ }^{14}$. Wartości te to najczęściej przedmioty i przekonania o nienormatywnym charakterze, które determinują względnie podobne przeżycia psychiczne i działania jednostek. Są to przekonania rozpowszechnione w grupie społecznej określające godne pożądania sądy i zachowania członków grupy, przekonania określające godne pożądania cechy grup społecznych lub społeczności ${ }^{15}$. Katolicka nauka społeczna przyczynia się do ich upowszechniania i pogłębiania ich przeżywania w polskim społeczeństwie.

Warto zatem się zastanowić, jaki jest stosunek młodzież do wartości społecznych, a zwłaszcza do ich zasadniczego zakresu, jakim są wartości podstawowe. Ich poglądy można poznać przez bezpośrednie

14 Por. W. Piwowarski, Stosunek uczniów i studentów do podstawowych wartości spoteczeństwa polskiego, „Życie Katolickie” 9 (1990), nr 2, s. 65.

15 Por. J. Mariański, Socjologia moralności, Lublin 2006, s. 338-339. 
badania poglądów młodzieży. Pewnym zobrazowaniem odniesienia młodzieży ponadgimnazjalnej do tego zakresu wartości są wyniki badania zrealizowanego w roku 2009/2010 w regionie konińskim ${ }^{16}$

Aby poznać świadomość młodego pokolenia do tego zakresu wartości, przedstawiono im listę wartości podstawowych, które są obecne w życiu społecznym. Ich przekonania przedstawia tabela $\mathrm{nr} 1$.

Tabela 1. Przekonanie o obecności wartości podstawowych w życiu społ. a płeć respondenta

\begin{tabular}{|c|c|c|c|c|}
\hline \multirow{2}{*}{\multicolumn{2}{|c|}{ Wartości podstawowe obecne w życiu publicznym }} & \multicolumn{2}{|c|}{ Płeć respondenta } & \multirow{2}{*}{$\begin{array}{c}\text { Ogółem } \\
893\end{array}$} \\
\hline & & \multirow{2}{*}{$\begin{array}{c}\mathrm{K} \\
424\end{array}$} & \multirow{2}{*}{$\begin{array}{c}M \\
469\end{array}$} & \\
\hline & Liczebność & & & \\
\hline & \% z Płeć respondenta & $60,0 \%$ & $75,4 \%$ & $67,2 \%$ \\
\hline \multirow{2}{*}{ Religia } & Liczebność & 383 & 292 & 675 \\
\hline & \% z Płeć respondenta & $54,2 \%$ & $46,9 \%$ & $50,8 \%$ \\
\hline \multirow{2}{*}{ Prawda } & Liczebność & 220 & 227 & 447 \\
\hline & $\%$ z Płeć respondenta & $31,1 \%$ & $36,5 \%$ & $33,6 \%$ \\
\hline \multirow{2}{*}{ Wolność } & Liczebność & 391 & 241 & 632 \\
\hline & \% z Płeć respondenta & $55,3 \%$ & $38,7 \%$ & $47,6 \%$ \\
\hline \multirow{2}{*}{ Demokracja } & Liczebność & 463 & 424 & 887 \\
\hline & \% z Płeć respondenta & $65,5 \%$ & $68,2 \%$ & $66,7 \%$ \\
\hline \multirow{2}{*}{ Sprawiedliwość społeczna } & Liczebność & 211 & 285 & 496 \\
\hline & $\%$ z Płeć respondenta & $29,8 \%$ & $45,8 \%$ & $37,3 \%$ \\
\hline \multirow{2}{*}{ Równość społeczna } & Liczebność & 139 & 111 & 250 \\
\hline & \% z Płeć respondenta & $19,7 \%$ & $17,8 \%$ & $18,8 \%$ \\
\hline \multirow{2}{*}{ Godność osoby ludzkiej } & Liczebność & 212 & 168 & 380 \\
\hline & $\%$ z Płeć respondenta & $30,0 \%$ & $27,0 \%$ & $28,6 \%$ \\
\hline \multirow{2}{*}{ Prawa człowieka } & Liczebność & 329 & 253 & 582 \\
\hline & $\%$ z Płeć respondenta & $46,5 \%$ & $40,7 \%$ & $43,8 \%$ \\
\hline \multirow{2}{*}{ Solidarność } & Liczebność & 288 & 295 & 583 \\
\hline & $\%$ z Płeć respondenta & $40,7 \%$ & $47,4 \%$ & $43,9 \%$ \\
\hline \multirow{2}{*}{ Ideały socjalistyczne } & Liczebność & 229 & 203 & 432 \\
\hline & $\%$ z Płeć respondenta & $32,4 \%$ & $32,6 \%$ & $32,5 \%$ \\
\hline \multirow{2}{*}{ Inne } & Liczebność & 70 & 121 & 191 \\
\hline & \% z Płeć respondenta & $9,9 \%$ & $19,5 \%$ & $14,4 \%$ \\
\hline
\end{tabular}

Uwaga: Wartości w kolumnach nie sumują się do 100\%, ponieważ respondenci mogli wybierać wiele wartości.

${ }^{16}$ Por. K. Skoczylas, Wartości młodych katolików regionu konińskiego, Toruń 2011. 
W przekonaniu młodzieży regionu konińskiego najbardziej obecne w życiu społecznym są: patriotyzm, demokracja, religia, wolność, solidarność, prawa człowieka, sprawiedliwość społeczna i ideały socjalistyczne. Aby przekonać się, czy młodzi akceptują ten stan rzeczy, zadano im pytanie, jakie wartości, twoim zdaniem, powinny być obecne w życiu społecznym. Poproszono młodych, aby wybrali z przedstawionej im poprzednio listy wartości, które ich zdaniem są pożądane w życiu społecznym. Ilustruje to tabela nr 2.

Tabela 2. Postulowane w życiu społ. wartości podstawowe a płeć respondenta

\begin{tabular}{|c|c|c|c|c|}
\hline \multirow{2}{*}{\multicolumn{2}{|c|}{ Wartości podstawowe postulowane w życiu publicznymM }} & \multicolumn{2}{|c|}{ Płeć respondenta } & \multirow{3}{*}{$\begin{array}{c}\text { Ogółem } \\
457 \\
\end{array}$} \\
\hline & & \multirow{2}{*}{$\frac{K}{291}$} & \multirow{2}{*}{$\begin{array}{c}M \\
166\end{array}$} & \\
\hline Patrintyzm & Liczebność & & & \\
\hline 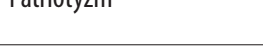 & $\%$ z Płeć respondenta & $41,2 \%$ & $26,7 \%$ & $34,4 \%$ \\
\hline \multirow{2}{*}{ Religia } & Liczebność & 339 & 300 & 639 \\
\hline & $\%$ z Płeć respondenta & $47,9 \%$ & $48,2 \%$ & $48,1 \%$ \\
\hline \multirow{2}{*}{ Prawda } & Liczebność & 492 & 381 & 873 \\
\hline & $\%$ z Płeć respondenta & $69,6 \%$ & $61,3 \%$ & $65,7 \%$ \\
\hline \multirow{2}{*}{ Wolność } & Liczebność & 332 & 368 & 700 \\
\hline & $\%$ z Płeć respondenta & $47,0 \%$ & $59,2 \%$ & $52,7 \%$ \\
\hline \multirow{2}{*}{ Demokracja } & Liczebność & 242 & 201 & 443 \\
\hline & $\%$ z Płeć respondenta & $34,2 \%$ & $32,3 \%$ & $33,3 \%$ \\
\hline \multirow{2}{*}{ Sprawiedliwość społeczna } & Liczebność & 492 & 326 & 818 \\
\hline & $\%$ z Płeć respondenta & $69,6 \%$ & $52,4 \%$ & $61,6 \%$ \\
\hline \multirow{2}{*}{ Równość społeczna } & Liczebność & 556 & 496 & 1052 \\
\hline & $\%$ z Płeć respondenta & $78,6 \%$ & $79,7 \%$ & $79,2 \%$ \\
\hline \multirow{2}{*}{ Godność osoby ludzkiej } & Liczebność & 489 & 426 & 915 \\
\hline & $\%$ z Płeć respondenta & $69,2 \%$ & $68,5 \%$ & $68,8 \%$ \\
\hline \multirow{2}{*}{ Prawa człowieka } & Liczebność & 383 & 363 & 746 \\
\hline & $\%$ z Płeć respondenta & $54,2 \%$ & $58,4 \%$ & $56,1 \%$ \\
\hline \multirow{2}{*}{ Solidarność } & Liczebność & 391 & 311 & 702 \\
\hline & $\%$ z Płeć respondenta & $55,3 \%$ & $50,0 \%$ & $52,8 \%$ \\
\hline \multirow{2}{*}{ Ideały socjalistyczne } & Liczebność & 314 & 260 & 574 \\
\hline & $\%$ z Płeć respondenta & $44,4 \%$ & $41,8 \%$ & $43,2 \%$ \\
\hline \multirow{2}{*}{ Inne } & Liczebność & 80 & 110 & 190 \\
\hline & $\%$ z Płeć respondenta & $11,3 \%$ & $17,7 \%$ & $14,3 \%$ \\
\hline
\end{tabular}

Uwaga: Wartości w kolumnach nie sumują się do 100\%, ponieważ respondenci mogli wybierać wiele wartości. 
Młodzi ludzie oczekują, że w życiu publicznym będzie respektowana równość społeczna $(79,2 \%)$, godność osoby ludzkiej $(68,8 \%)$, oraz prawda $(65,7 \%)$ a także sprawiedliwość społeczna $(61,6 \%)$. W dalszej kolejności ważne są dla nich: prawa człowieka $(56,1 \%)$, solidarność $(52,8 \%)$ i wolność $(52,7 \%)$. Zatem młodzi nie akceptują w pełnym zakresie zastanego zbioru wartości w życiu publicznym. Można się spodziewać, że, gdy dana będzie im taką możliwość, będą dążyć do zmian $\mathrm{w}$ życiu publicznym $\mathrm{w}$ taki sposób, aby wartości ich zdaniem ważne były bardziej obecne w nim ${ }^{17}$.

O sile przywiązania do wartości podstawowych świadczy gotowość oddania życia dla ich ratowania. To przywiązanie do nich przedstawia tabela nr 3.

Tabela 3. Gotowość narażania życia dla prawdy a płeć respondenta

\begin{tabular}{|l|l|c|c|c|}
\hline \multirow{2}{*}{ Gotowość narażania życia w obronie prawdy } & \multicolumn{2}{c|}{ Płeć respondenta } & \multirow{2}{*}{ Ogółem } \\
\cline { 3 - 4 } & Liczebność & K & M & \\
\hline \multirow{2}{*}{ Tak } & \% z Płeć respondenta & 214 & 141 & 355 \\
\hline \multirow{2}{*}{ Nie } & Liczebność & $30,3 \%$ & $22,7 \%$ & $26,7 \%$ \\
\cline { 2 - 5 } & \% z Płeć respondenta & $12,2 \%$ & $7,4 \%$ & $9,9 \%$ \\
\hline \multirow{2}{*}{ Trudno mi powiedzieć } & Liczebność & 178 & 101 & 279 \\
\cline { 2 - 5 } & \% z Płeć respondenta & $25,2 \%$ & $16,2 \%$ & $21,0 \%$ \\
\hline Brak danych & Liczebność & 229 & 334 & 563 \\
\cline { 2 - 5 } & \% z Płeć respondenta & $32,4 \%$ & $53,7 \%$ & $42,4 \%$ \\
\hline \multirow{2}{*}{ 0gółem } & Liczebność & 707 & 622 & 1329 \\
\cline { 2 - 5 } & \% z Płeć respondenta & $100,0 \%$ & $100,0 \%$ & $100,0 \%$ \\
\hline
\end{tabular}

Choć młodzi deklarowali, że prawda jest dla nich bardzo ważna, to jednak gotowość oddania życia dla niej deklaruje tylko co trzeci respondent $(26,7 \%)$. Duża grupa badanych nie potrafi też określić swoje odniesienia do tej wartości (21\%). Dość duża grupa deklaruje, że nie ryzykowałaby własnego życia dla obrony prawdy $(9,9 \%)^{18}$.

Badani bardzo często podkreślali, że powinna być w życiu społecznym równość społeczna. Jakie ona ma dla nich znaczenie świadczy gotowość oddania dla niej życia. Postawy młodzieży regionu konińskiego przedstawia tabela $\mathrm{nr} 4$

17 Tamże, s. 448-451.

18 Tamże, s. 452. 
Tabela 4. Gotowość narażania życia w obronie równości społecznej a płeć respondenta

\begin{tabular}{|c|c|c|c|c|}
\hline \multirow{2}{*}{\multicolumn{2}{|c|}{ Gotowość narażania życia w obronie równości społecznej }} & \multicolumn{2}{|c|}{ Płeć respondenta } & \multirow{3}{*}{$\begin{array}{c}\text { Ogółem } \\
523 \\
\end{array}$} \\
\hline & & \multirow{2}{*}{$\begin{array}{c}K \\
264\end{array}$} & \multirow{2}{*}{$\begin{array}{c}M \\
259\end{array}$} & \\
\hline Tak & Liczebność & & & \\
\hline & $\%$ z Płeć respondenta & $37,3 \%$ & $41,6 \%$ & $39,4 \%$ \\
\hline \multirow[t]{2}{*}{ Nie } & Liczebność & 132 & 101 & 233 \\
\hline & $\%$ z Płeć respondenta & $18,7 \%$ & $16,2 \%$ & $17,5 \%$ \\
\hline \multirow[t]{2}{*}{ Trudno mi powiedzieć } & Liczebność & 267 & 242 & 509 \\
\hline & $\%$ z Płeć respondenta & $37,8 \%$ & $38,9 \%$ & $38,3 \%$ \\
\hline \multirow[t]{2}{*}{ Brak danych } & Liczebność & 44 & 20 & 64 \\
\hline & $\%$ z Płeć respondenta & $6,2 \%$ & $3,2 \%$ & $4,8 \%$ \\
\hline \multirow[t]{2}{*}{ Ogółem } & Liczebność & 707 & 622 & 1329 \\
\hline & \% z Płeć respondenta & $100,0 \%$ & $100,0 \%$ & $100,0 \%$ \\
\hline
\end{tabular}

Dla równości społecznej gotowych jest oddać życie nieco więcej badanych $(39,4 \%)$ niż dla prawdy. Zarazem więcej badanych deklaruje, że dla takiej wartości nie zaryzykowałoby życia (17,5\%). Bardzo duża grupa nie potrafi zająć wobec tego stanowiska. Można więc przypuszczać, że znaczna grupa nie ma na ten temat wyrobionego poglądu $(38,3 \%)^{19}$.

Badani deklarowali, że chcą intensywniejszej obecności sprawiedliwości społecznej. Ich gotowość oddania życia dla obrony sprawiedliwości przedstawia tabela nr 5 .

Tabela 5. Gotowość narażania życia dla sprawiedliwości a płeć respondenta

\begin{tabular}{|c|c|c|c|c|}
\hline \multirow{2}{*}{\multicolumn{2}{|c|}{ Gotowość narażania życia w obronie sprawiedliwości }} & \multicolumn{2}{|c|}{ Płeć respondenta } & \multirow{3}{*}{$\begin{array}{c}\text { Ogółem } \\
825\end{array}$} \\
\hline & & \multirow{2}{*}{$\begin{array}{c}\mathrm{K} \\
411\end{array}$} & \multirow{2}{*}{$\frac{M}{414}$} & \\
\hline Tak & Liczebność & & & \\
\hline & \% z Płeć respondenta & $58,1 \%$ & $66,6 \%$ & $62,1 \%$ \\
\hline \multirow[t]{2}{*}{ Nie } & Liczebność & 76 & 48 & 124 \\
\hline & $\%$ z Płeć respondenta & $10,7 \%$ & $7,7 \%$ & $9,3 \%$ \\
\hline \multirow[t]{2}{*}{ Trudno mi powiedzieć } & Liczebność & 180 & 141 & 321 \\
\hline & $\%$ z Płeć respondenta & $25,5 \%$ & $22,7 \%$ & $24,2 \%$ \\
\hline \multirow[t]{2}{*}{ Brak danych } & Liczebność & 40 & 19 & 59 \\
\hline & $\%$ z Płeć respondenta & $5,7 \%$ & $3,1 \%$ & $4,4 \%$ \\
\hline \multirow[t]{2}{*}{ Ogółem } & Liczebność & 707 & 622 & 1329 \\
\hline & $\%$ z Płeć respondenta & $100,0 \%$ & $100,0 \%$ & $100,0 \%$ \\
\hline
\end{tabular}

19 Tamże, s. 457. 
Tabela nr 5 wskazuje, że młodzież jest bardzo wrażliwa na sprawiedliwość. Dla obrony sprawiedliwości gotowość oddania życia deklaruje większość badanych (62,1\%). Mniejsza grupa niż w odniesieniu do obrony równości społecznej deklaruje, że nie oddałaby życia za obronę sprawiedliwości $(9,3 \%)$. Wielu młodych nie potrafi jednak i wobec tej wartości zająć jednoznacznego stanowiska $(24,2 \%)^{20}$.

Także godność osoby ludzkiej powinna być chroniona w życiu publicznym. Zapytano zatem respondentów, czy oddaliby życie dla obrony godności ludzkiej. Ich przekonania przestawia tabela nr 6 .

Tabela 6. Gotowość narażania życia w obronie godności ludzkiej a płeć respondenta

\begin{tabular}{|c|c|c|c|c|}
\hline \multirow{2}{*}{\multicolumn{2}{|c|}{ Gotowość narażania życia w obronie sprawiedliwości }} & \multicolumn{2}{|c|}{ Płeć respondenta } & \multirow{3}{*}{$\begin{array}{c}\text { Ogółem } \\
867\end{array}$} \\
\hline & & \multirow{2}{*}{$\begin{array}{c}K \\
439\end{array}$} & \multirow{2}{*}{$\begin{array}{c}M \\
428\end{array}$} & \\
\hline Tak & Liczebność & & & \\
\hline & $\%$ z Płeć respondenta & $62,1 \%$ & $68,8 \%$ & $65,2 \%$ \\
\hline \multirow[t]{2}{*}{ Nie } & Liczebność & 46 & 31 & 77 \\
\hline & \% z Płeć respondenta & $6,5 \%$ & $5,0 \%$ & $5,8 \%$ \\
\hline \multirow[t]{2}{*}{ Trudno mi powiedzieć } & Liczebność & 188 & 147 & 335 \\
\hline & \% z Płeć respondenta & $26,6 \%$ & $23,6 \%$ & $25,2 \%$ \\
\hline \multirow[t]{2}{*}{ Brak danych } & Liczebność & 34 & 16 & 50 \\
\hline & \% z Płeć respondenta & $4,8 \%$ & $2,6 \%$ & $3,8 \%$ \\
\hline \multirow[t]{2}{*}{ Ogółem } & Liczebność & 707 & 622 & 1329 \\
\hline & \% z Płeć respondenta & $100,0 \%$ & $100,0 \%$ & $100,0 \%$ \\
\hline
\end{tabular}

Tabela nr 6 potwierdza wielkie przywiązanie dla ochrony godności osoby ludzkiej. Potwierdzają to wyniki zawarte w tej tabeli. Gotowość oddania życia dla jej obrony deklaruje $65,2 \%$ badanych, przeciwne przekonanie wyraża zaledwie 5,8\%, natomiast nie potrafi określić się wobec tej wartości $25,2 \%$ badanych $^{21}$.

Badani pragną, aby istniała wolność w życiu publicznym. O znaczeniu przypisywanemu tej wartości świadczy wymownie gotowość poświęcenia własnego życia dla jej obrony. Poglądy młodzieży przedstawia tabela $\mathrm{nr} 7$.

Wyniki badań potwierdzają przywiązanie młodych do wolności.

\footnotetext{
20 Tamże, s. 454.

${ }^{21}$ Tamże, s. 460.
} 
Tabela 7. Gotowość narażania życia dla obrony wolności a płeć respondenta

\begin{tabular}{|c|c|c|c|c|}
\hline \multirow{2}{*}{\multicolumn{2}{|c|}{ Gotowość narażania życia w obronie wolności }} & \multicolumn{2}{|c|}{ Płeć respondenta } & \multirow{3}{*}{$\begin{array}{c}\text { Ogółem } \\
854\end{array}$} \\
\hline & & \multirow{2}{*}{$\begin{array}{c}\mathrm{K} \\
449\end{array}$} & \multirow{2}{*}{$\frac{M}{405}$} & \\
\hline Tak & Liczebność & & & \\
\hline & $\%$ z Płeć respondenta & $63,5 \%$ & $65,1 \%$ & $64,3 \%$ \\
\hline \multirow[t]{2}{*}{ Nie } & Liczebność & 62 & 40 & 102 \\
\hline & \% z Płeć respondenta & $8,8 \%$ & $6,4 \%$ & $7,7 \%$ \\
\hline \multirow[t]{2}{*}{ Trudno mi powiedzieć } & Liczebność & 161 & 162 & 323 \\
\hline & \% z Płeć respondenta & $22,8 \%$ & $26,0 \%$ & $24,3 \%$ \\
\hline \multirow[t]{2}{*}{ Brak danych } & Liczebność & 35 & 15 & 50 \\
\hline & \% z Płeć respondenta & $5,0 \%$ & $2,4 \%$ & $3,8 \%$ \\
\hline \multirow[t]{2}{*}{ Ogółem } & Liczebność & 707 & 622 & 1329 \\
\hline & \% z Płeć respondenta & $100,0 \%$ & $100,0 \%$ & $100,0 \%$ \\
\hline
\end{tabular}

Jak wynika z tabeli nr 7,64,3\% młodych gotowych jest oddać życie dla obrony wolności. Nie zrobiłoby tego $7,7 \%$, natomiast także tu $24,3 \%$ nie ma wyrobionego zdania ${ }^{22}$. Konkretnym przejawem wolności jest istnienie własnej Ojczyzny. Przywiązanie do Ojczyzny prezentuje tabela nr 8.

Tabela 8. Gotowość narażania życia dla 0jczyzny a pleć respondenta

\begin{tabular}{|c|c|c|c|c|}
\hline \multirow{2}{*}{\multicolumn{2}{|c|}{ Gotowość narażania życia w obronie 0jczyzny }} & \multicolumn{2}{|c|}{ Płeć respondenta } & \multirow{3}{*}{$\begin{array}{c}\text { Ogółem } \\
750 \\
\end{array}$} \\
\hline & & \multirow{2}{*}{$\begin{array}{c}K \\
386\end{array}$} & \multirow{2}{*}{$\begin{array}{c}M \\
364\end{array}$} & \\
\hline Tak & Liczebność & & & \\
\hline & $\%$ z Płeć respondenta & $54,6 \%$ & $58,5 \%$ & $56,4 \%$ \\
\hline \multirow[t]{2}{*}{ Nie } & Liczebność & 99 & 62 & 161 \\
\hline & $\%$ z Płeć respondenta & $14,0 \%$ & $10,0 \%$ & $12,1 \%$ \\
\hline \multirow[t]{2}{*}{ Trudno mi powiedzieć } & Liczebność & 188 & 181 & 369 \\
\hline & \% z Płeć respondenta & $26,6 \%$ & $29,1 \%$ & $27,8 \%$ \\
\hline \multirow[t]{2}{*}{ Brak danych } & Liczebność & 34 & 15 & 49 \\
\hline & $\%$ z Płeć respondenta & $4,8 \%$ & $2,4 \%$ & $3,7 \%$ \\
\hline \multirow[t]{2}{*}{ Ogółem } & Liczebność & 707 & 622 & 1329 \\
\hline & \% z Płeć respondenta & $100,0 \%$ & $100,0 \%$ & $100,0 \%$ \\
\hline
\end{tabular}

Wśród wartości ważnych dla życia społecznego jest też religia. O przywiązaniu do niej świadczy gotowość oddania życia. To, jakie jest przywiązanie do religii, mówi tabela nr 9 .

${ }^{22}$ Tamże s. 455.

${ }^{23}$ Tamże, s. 453. 
Tabela 9. Gotowość narażania życia w obronie religii a płeć respondenta

\begin{tabular}{|c|c|c|c|c|}
\hline \multirow{2}{*}{\multicolumn{2}{|c|}{ Gotowość narażania życia w obronie religii }} & \multicolumn{2}{|c|}{ Płeć respondenta } & \multirow{3}{*}{$\begin{array}{c}\text { Ogółem } \\
551\end{array}$} \\
\hline & & \multirow{2}{*}{$\begin{array}{c}\mathrm{K} \\
318\end{array}$} & \multirow{2}{*}{$\begin{array}{c}M \\
233\end{array}$} & \\
\hline Tak & Liczebność & & & \\
\hline & $\%$ z Płeć respondenta & $45,0 \%$ & $37,5,5 \%$ & $41,5 \%$ \\
\hline \multirow[t]{2}{*}{ Nie } & Liczebność & 99 & 99 & 198 \\
\hline & $\%$ z Płeć respondenta & $14,0 \%$ & $15,9 \%$ & $14,9 \%$ \\
\hline \multirow[t]{2}{*}{ Trudno mi powiedzieć } & Liczebność & 258 & 273 & 531 \\
\hline & \% z Płeć respondenta & $36,5 \%$ & $43,9 \%$ & $40,0 \%$ \\
\hline \multirow[t]{2}{*}{ Brak danych } & Liczebność & 32 & 17 & 49 \\
\hline & $\%$ z Płeć respondenta & $4,5 \%$ & $2,7 \%$ & $3,7 \%$ \\
\hline \multirow[t]{2}{*}{ Ogółem } & Liczebność & 707 & 622 & 1329 \\
\hline & $\%$ z Płeć respondenta & $100,0 \%$ & $100,0 \%$ & $100,0 \%$ \\
\hline
\end{tabular}

W przekonaniu młodzieży religia nie przedstawia tak wielkiej wartości jak wolność, równość społeczna czy godność osoby. Jednak, mimo to, wielkie jest przywiązanie do niej młodego pokolenia. Gotowość oddania za nią życia deklaruje 41,5\%. Jednak $14,9 \%$ nie ryzykowałoby dla niej życia. Także ogromna grupa (40\%) nie umie odnieść się to tej wartości ${ }^{24}$.

Ważną dziedziną życia społecznego jest praca i sprawiedliwość rządzącą rzeczywistością pracy ludzkiej. O znaczeniu przypisywanemu tej wartości świadczy sytuacja wynagradzania za pracę. Poproszono młodzież o ocenę sytuacji, gdy za tę samą pracę różnie wynagradza się pracowników. Ich oceny przedstawia tabela nr 10.

Większość młodzieży wyraża przekonanie, że lepsze wynagradzanie niektórych pracowników za tę samą pracę nie jest słuszne (48,8\%). Jednak duża grupa (33\%) uważa, że takie zachowanie ze strony pracodawcy nie jest sprzeczne ze sprawiedliwością. Ta grupa jest skłonna akceptować pewne formy niesprawiedliwości na płaszczyźnie życia gospodarczego ${ }^{25}$.

Wychowanie do życia społecznego w podstawowym zakresie odbywa się w rodzinie i w Kościele. Stąd warto zapytać, jakie wartości akceptują młodzi w wychowaniu rodzinnym. Wartości upowszechniane przez wychowanie $\mathrm{w}$ rodzinie są fundamentem dla życia społecznego w przyszłości. Przekonania młodych odnoszące się do wartości istotnych w wychowaniu rodziny przedstawia tabela $\mathrm{nr} 11$.

\footnotetext{
${ }^{24}$ Tamże s. 458.

${ }^{25}$ Tamże, s. 468-469.
} 
Tabela 10. Oceny nierównego traktowania pracowników a płeć respondenta

\begin{tabular}{|c|c|c|c|c|}
\hline \multirow{2}{*}{\multicolumn{2}{|c|}{ Oceny nierównego traktowania pracowników }} & \multicolumn{2}{|c|}{ Płeć respondenta } & \multirow{3}{*}{$\begin{array}{r}\text { Ogółem } \\
439\end{array}$} \\
\hline & & \multirow{2}{*}{$\frac{K}{246}$} & \multirow{2}{*}{$\begin{array}{c}\mathrm{M} \\
193\end{array}$} & \\
\hline Tak, jest słuszne, że lepiej płacono & Liczebność & & & \\
\hline pracę & $\%$ z Płeć respondenta & $34,8 \%$ & $31,0 \%$ & $33,0 \%$ \\
\hline \multirow{2}{*}{$\begin{array}{l}\text { Nie, nie jest słuszne lepiej płacić } \\
\text { jednej pracowniczce za taką samą } \\
\text { pracę }\end{array}$} & Liczebność & 332 & 317 & 649 \\
\hline & $\%$ z Płeć respondenta & $47,0 \%$ & $51,0 \%$ & $48,8 \%$ \\
\hline \multirow[t]{2}{*}{ Trudno mi powiedzieć } & Liczebność & 129 & 112 & 241 \\
\hline & $\%$ z Płeć respondenta & $18,2 \%$ & $18,0 \%$ & $18,1 \%$ \\
\hline \multirow[t]{2}{*}{ Ogółem } & Liczebność & 707 & 622 & 1329 \\
\hline & $\%$ z Płeć respondenta & $100,0 \%$ & $100,0 \%$ & $100,0 \%$ \\
\hline
\end{tabular}

Tabela 11. Wartości ważne w wychowaniu dzieci a płeć respondenta

\begin{tabular}{|c|c|c|c|c|}
\hline \multirow{2}{*}{\multicolumn{2}{|c|}{ Wartości ważne w wychowaniu dzieci }} & \multicolumn{2}{|c|}{ Płeć respondenta } & \multirow{3}{*}{$\begin{array}{c}\text { Ogółem } \\
5\end{array}$} \\
\hline & & \multirow{2}{*}{$\begin{array}{l}K \\
3\end{array}$} & \multirow{2}{*}{$\begin{array}{l}M \\
4\end{array}$} & \\
\hline 1 & 2 & & & \\
\hline \multirow[t]{2}{*}{ Oszczędność } & Liczebność & 71 & 73 & 144 \\
\hline & $\%$ z Płeć respondenta & $10,0 \%$ & $11,7 \%$ & $10,8 \%$ \\
\hline \multirow[t]{2}{*}{ Uczciwość } & Liczebność & 194 & 138 & 332 \\
\hline & \% z Płeć respondenta & $27,4 \%$ & $22,2 \%$ & $25,0 \%$ \\
\hline \multirow[t]{2}{*}{ Sumienność } & Liczebność & 102 & 205 & 307 \\
\hline & \% z Płeć respondenta & $14,4 \%$ & $33,0 \%$ & $23,1 \%$ \\
\hline \multirow[t]{2}{*}{ Pracowitość } & Liczebność & 55 & 64 & 119 \\
\hline & \% z Płeć respondenta & $7,8 \%$ & $10,3 \%$ & $9,0 \%$ \\
\hline \multirow[t]{2}{*}{ Opanowanie } & Liczebność & 19 & 3 & 22 \\
\hline & \% z Płeć respondenta & $2,7 \%$ &, $5 \%$ & $1,7 \%$ \\
\hline \multirow[t]{2}{*}{ Wytrwałość } & Liczebność & 7 & 7 & 14 \\
\hline & \% z Płeć respondenta & $1,0 \%$ & $1,1 \%$ & $1,1 \%$ \\
\hline \multirow[t]{2}{*}{ Posłuszeństwo } & Liczebność & 4 & 2 & 6 \\
\hline & \% z Płeć respondenta & $0,6 \%$ & $0,3 \%$ & $0,5 \%$ \\
\hline \multirow[t]{2}{*}{ Szacunek dla samego siebie } & Liczebność & 56 & 19 & 75 \\
\hline & \% z Płeć respondenta & $7,9 \%$ & $3,1 \%$ & $5,6 \%$ \\
\hline \multirow[t]{2}{*}{ Cierpliwość } & Liczebność & 6 & 8 & 14 \\
\hline & $\%$ z Płeć respondenta & $0,8 \%$ & $1,3 \%$ & $1,1 \%$ \\
\hline \multirow[t]{2}{*}{ Lojalność } & Liczebność & 4 & 5 & 9 \\
\hline & \% z Płeć respondenta & $0,6 \%$ & $0,8 \%$ & $0,7 \%$ \\
\hline
\end{tabular}


Ciąg dalszy tabeli 11. Wartości ważne w wychowaniu dzieci a płeć respondenta

\begin{tabular}{|c|c|c|c|c|}
\hline 1 & 2 & 3 & 4 & 5 \\
\hline \multirow[t]{2}{*}{ Dobre obyczaje } & Liczebność & 2 & 3 & 5 \\
\hline & $\%$ z Płeć respondenta & $0,3 \%$ & $0,5 \%$ & $0,4 \%$ \\
\hline \multirow[t]{2}{*}{ Poznawanie cudzej własności } & Liczebność & 5 & 1 & 6 \\
\hline & $\%$ z Płeć respondenta & $0,7 \%$ & $0,2 \%$ & $0,5 \%$ \\
\hline \multirow[t]{2}{*}{ Tolerancja } & Liczebność & 35 & 18 & 53 \\
\hline & $\%$ z Płeć respondenta & $5,0 \%$ & $2,9 \%$ & $4,0 \%$ \\
\hline \multirow[t]{2}{*}{ Wiara religijna } & Liczebność & 73 & 37 & 110 \\
\hline & $\%$ z Płeć respondenta & $10,3 \%$ & $5,9 \%$ & $8,3 \%$ \\
\hline \multirow[t]{2}{*}{ Odpowiedzialność } & Liczebność & 25 & 14 & 39 \\
\hline & $\%$ z Płeć respondenta & $3,5 \%$ & $2,3 \%$ & $2,9 \%$ \\
\hline \multirow[t]{2}{*}{ Bezinteresowność } & Liczebność & 9 & 2 & 11 \\
\hline & $\%$ z Płeć respondenta & $1,3 \%$ &, $3 \%$ &, $8 \%$ \\
\hline \multirow[t]{2}{*}{ Samodzielność } & Liczebność & 6 & 8 & 14 \\
\hline & $\%$ z Płeć respondenta & $0,8 \%$ & $1,3 \%$ & $1,1 \%$ \\
\hline \multirow[t]{2}{*}{ Prawdomówność } & Liczebność & 25 & 7 & 32 \\
\hline & $\%$ z Płeć respondenta & $3,5 \%$ & $1,1 \%$ & $2,4 \%$ \\
\hline \multirow[t]{2}{*}{ Systematyczność } & Liczebność & 1 & 0 & 1 \\
\hline & \% z Płeć respondenta & $0,1 \%$ & $0,0 \%$ & $0,1 \%$ \\
\hline \multirow[t]{2}{*}{ Punktualność } & Liczebność & 2 & 0 & 2 \\
\hline & \% z Płeć respondenta &, $3 \%$ &, $0 \%$ &, $2 \%$ \\
\hline \multirow[t]{2}{*}{ Brak danych } & Liczebność & 6 & 8 & 14 \\
\hline & $\%$ z Płeć respondenta & $0,8 \%$ & $1,3 \%$ & $1,1 \%$ \\
\hline \multirow[t]{2}{*}{ Ogółem } & Liczebność & 707 & 622 & 1329 \\
\hline & $\%$ z Płeć respondenta & $100,0 \%$ & $100,0 \%$ & $100,0 \%$ \\
\hline
\end{tabular}

Dla badanej młodzieży w wychowaniu dzieci szczególnie ważne są uczciwość (25\%), sumienność (23,1\%), oszczędność (10,8\%), pracowitość $(9 \%)$, wiara religijna $(8,4 \%)$ i szacunek dla samego siebie $(5,6 \%)^{26}$. O wychowaniu rodzinnym decydują także przekonania młodych odnoszące się do zobowiązań rodziców wobec dzieci. Jedni rodzice sądzą, że powinni zapewnić wszystko swoim dzieciom, nawet ze szkodą dla siebie, a inni uważają, że rodzice mają swoje życie i nie powinno się zbyt wiele od nich oczekiwać. Przekonania młodzieży odnoszące się do zobowiązań rodziców wobec dzieci przedstawia tabela nr 12.

${ }^{26}$ Tamże, s. 481-483. 
Tabela 12. Zobowiązania rodziców wobec dzieci a płeć respondenta

\begin{tabular}{|c|c|c|c|c|}
\hline \multirow{2}{*}{\multicolumn{2}{|c|}{ Zobowiązania rodziców wobec dzieci }} & \multicolumn{2}{|c|}{ Płeć respondenta } & \multirow{2}{*}{$\begin{array}{c}\text { Ogółem } \\
609\end{array}$} \\
\hline & & & & \\
\hline Obowiązkiem rodziców jest dawać & Liczebność & $\begin{array}{c}\text { K } \\
392\end{array}$ & $\begin{array}{c}M \\
317\end{array}$ & \\
\hline & $\%$ z Płeć respondenta & $41,3 \%$ & $51,0 \%$ & $45,8 \%$ \\
\hline \multirow{2}{*}{$\begin{array}{l}\text { Rodzice mają własne życie i nie } \\
\text { powinno się tego wymagać }\end{array}$} & Liczebność & 86 & 87 & 173 \\
\hline & $\%$ z Płeć respondenta & $12,2 \%$ & $14,0 \%$ & $13,0 \%$ \\
\hline \multirow[t]{2}{*}{ Ani jedno ani drugie } & Liczebność & 215 & 124 & 339 \\
\hline & $\%$ z Płeć respondenta & $30,4 \%$ & $19,9 \%$ & $25,5 \%$ \\
\hline \multirow[t]{2}{*}{ Trudno mi powiedzieć } & Liczebność & 109 & 91 & 200 \\
\hline & $\%$ z Płeć respondenta & $15,4 \%$ & $14,6 \%$ & $15,0 \%$ \\
\hline \multirow[t]{2}{*}{ Brak danych } & Liczebność & 5 & 3 & 8 \\
\hline & $\%$ z Płeć respondenta & $0,7 \%$ & $0,5 \%$ & $0,6 \%$ \\
\hline \multirow[t]{2}{*}{ Ogółem } & Liczebność & 707 & 622 & 1329 \\
\hline & $\%$ z Płeć respondenta & $100,0 \%$ & $100,0 \%$ & $100,0 \%$ \\
\hline
\end{tabular}

Znacząca grupa badanych $(45,8 \%)$ uważa, że rodzice powinni się radykalnie poświęcić dla swoich dzieci i zapewnić im wszystko. Mniejsza grupa sądzi, że rodzice mają swoje życie i nie powinni zbytnio zajmować się dziećmi. Bardzo duża grupa $(25,5 \%)$ opowiada się za umiarkowanym poświęceniem rodziców na rzecz swoich dzieci. W całej badanej populacji przeważa przekonanie, że rodzice powinni bardzo intensywnie lub intensywnie poświęcać się dla swoich dzieci $(71,3 \%)^{27}$.

Oprócz rodziny także Kościół katolicki w Polsce uczestniczy w kształtowaniu postaw wobec życia społecznego. Rolę Kościoła w tym procesie spostrzegają bardzo krytycznie ludzie młodzi. Zapytano ich, czy Kościół udziela wystarczających odpowiedzi na problemy rodziny, młodzieży i warstw społecznych. Przedstawiają to tabele nr 13, 14 i 15.

W badanej grupie młodzieży prawie taka sama liczba młodych jest przekonana, że Kościół odpowiedzi Kościoła na problemy rodziny są adekwatne $(14,7 \%)$ i nieadekwatne $(18,7 \%)$. Pozytywnie zaangażowanie Kościoła na rzecz rodziny ocenia 50,6\% badanych. Niewystarczające jest zaangażowanie Kościoła na rzecz rodziny w opinii 33,4\% młodych. Wkład Kościoła na rzecz rodziny przez znaczną grupę młodych oceniany jest krytycznie ${ }^{28}$.

27 Tamże, s. 479-481.

28 Tamże, s. 473. 
Tabela 13. Odpowiedzi Kościoła na problemy rodziny a płeć respondenta

\begin{tabular}{|c|c|c|c|c|}
\hline \multirow{2}{*}{\multicolumn{2}{|c|}{ Zobowiązania rodziców wobec dzieci }} & \multicolumn{2}{|c|}{ Płeć respondenta } & \multirow{3}{*}{$\begin{array}{c}\text { Ogółem } \\
196\end{array}$} \\
\hline & & \multirow{2}{*}{$\begin{array}{c}\mathrm{K} \\
116\end{array}$} & \multirow{2}{*}{$\begin{array}{l}M \\
80\end{array}$} & \\
\hline Tak & Liczebność & & & \\
\hline & $\%$ z Płeć respondenta & $16,4 \%$ & $12,9 \%$ & $14,7 \%$ \\
\hline \multirow[t]{2}{*}{ Częściowo tak } & Liczebność & 253 & 224 & 477 \\
\hline & $\%$ z Płeć respondenta & $35,8 \%$ & $36,0 \%$ & $35,9 \%$ \\
\hline \multirow[t]{2}{*}{ Częściowo nie } & Liczebność & 102 & 93 & 195 \\
\hline & $\%$ z Płeć respondenta & $14,4 \%$ & $15,0 \%$ & $14,7 \%$ \\
\hline \multirow[t]{2}{*}{ Nie } & Liczebność & 118 & 130 & 248 \\
\hline & $\%$ z Płeć respondenta & $16,7 \%$ & $20,9 \%$ & $18,7 \%$ \\
\hline \multirow[t]{2}{*}{ Trudno mi powiedzieć } & Liczebność & 91 & 85 & 176 \\
\hline & $\%$ z Płeć respondenta & $12,9 \%$ & $13,7 \%$ & $13,2 \%$ \\
\hline \multirow[t]{2}{*}{ Brak danych } & Liczebność & 27 & 10 & 37 \\
\hline & \% z Płeć respondenta & $3,8 \%$ & $1,6 \%$ & $2,8 \%$ \\
\hline \multirow[t]{2}{*}{ Ogółem } & Liczebność & 707 & 622 & 1329 \\
\hline & $\%$ z Płeć respondenta & $100,0 \%$ & $100,0 \%$ & $100,0 \%$ \\
\hline
\end{tabular}

Tabela 14. Odpowiedzi Kościoła na problemy młodzieży a płeć respondenta

\begin{tabular}{|c|c|c|c|c|}
\hline \multirow{2}{*}{\multicolumn{2}{|c|}{ Odpowiedzi Kościoła na problemy młodzieży }} & \multicolumn{2}{|c|}{ Płeć respondenta } & \multirow{3}{*}{$\begin{array}{c}\text { Ogółem } \\
220\end{array}$} \\
\hline & & \multirow{2}{*}{$\begin{array}{c}\mathrm{K} \\
123\end{array}$} & \multirow{2}{*}{$\begin{array}{l}\text { M } \\
97\end{array}$} & \\
\hline Tak & Liczebność & & & \\
\hline & $\%$ z Płeć respondenta & $17,4 \%$ & $15,6 \%$ & $16,6 \%$ \\
\hline \multirow[t]{2}{*}{ Częściowo tak } & Liczebność & 237 & 227 & 464 \\
\hline & \% z Płeć respondenta & $33,5 \%$ & $36,5 \%$ & $34,9 \%$ \\
\hline \multirow[t]{2}{*}{ Częściowo nie } & Liczebność & 100 & 89 & 189 \\
\hline & \% z Płeć respondenta & $14,1 \%$ & $14,3 \%$ & $14,2 \%$ \\
\hline \multirow[t]{2}{*}{ Nie } & Liczebność & 137 & 130 & 267 \\
\hline & \% z Płeć respondenta & $19,4 \%$ & $20,9 \%$ & $20,1 \%$ \\
\hline \multirow[t]{2}{*}{ Trudno mi powiedzieć } & Liczebność & 78 & 67 & 145 \\
\hline & $\%$ z Płeć respondenta & $11,0 \%$ & $10,8 \%$ & $10,9 \%$ \\
\hline \multirow[t]{2}{*}{ Brak danych } & Liczebność & 32 & 12 & 44 \\
\hline & $\%$ z Płeć respondenta & $4,5 \%$ & $1,9 \%$ & $3,3 \%$ \\
\hline \multirow[t]{2}{*}{ Ogółem } & Liczebność & 707 & 622 & 1329 \\
\hline & $\%$ z Płeć respondenta & $100,0 \%$ & $100,0 \%$ & $100,0 \%$ \\
\hline
\end{tabular}


Jeszcze bardziej krytycznie oceniany jest wkład Kościoła w życie młodych. Większa grupa badanych niż w odniesieniu do rodziny jest takich, którzy twierdzą, że Kościół nie udziela wystarczających odpowiedzi na problemy młodzieży (20,1\%). Gdy weźmie się pod uwagę tych, którzy wyrażają przekonanie, że Kościół częściowo nie udziela odpowiedzi na ich problemy $(14,2 \%)$, to grupa osób rozczarowanych zaangażowaniem Kościoła na rzecz młodzieży wzrasta do $34,3 \%$. Z tego przekonania może rodzić się dystans wobec młodych wobec Kościoła, a nawet oddalenie się od niego ${ }^{29}$.

Tabela 15. Odpowiedzi Kościoła na problemy warstw społecznych a płeć respondenta

\begin{tabular}{|c|c|c|c|c|}
\hline \multirow{2}{*}{\multicolumn{2}{|c|}{ Odpowiedzi Kościoła na problemy społeczne }} & \multicolumn{2}{|c|}{ Płeć respondenta } & \multirow{3}{*}{$\begin{array}{c}\text { Ogółem } \\
166\end{array}$} \\
\hline & & \multirow{2}{*}{$\frac{\mathrm{K}}{94}$} & \multirow{2}{*}{$\begin{array}{c}M \\
72\end{array}$} & \\
\hline Tak & Liczebność & & & \\
\hline & $\%$ z Płeć respondenta & $13,3 \%$ & $11,6 \%$ & $12,5 \%$ \\
\hline \multirow[t]{2}{*}{ Częściowo tak } & Liczebność & 185 & 181 & 366 \\
\hline & $\%$ z Płeć respondenta & $26,2 \%$ & $29,1 \%$ & $27,5 \%$ \\
\hline \multirow[t]{2}{*}{ Częściowo nie } & Liczebność & 121 & 118 & 239 \\
\hline & $\%$ z Płeć respondenta & $17,1 \%$ & $19,0 \%$ & $18,0 \%$ \\
\hline \multirow[t]{2}{*}{ Nie } & Liczebność & 163 & 158 & 321 \\
\hline & $\%$ z Płeć respondenta & $23,1 \%$ & $25,4 \%$ & $24,2 \%$ \\
\hline \multirow[t]{2}{*}{ Trudno mi powiedzieć } & Liczebność & 117 & 83 & 200 \\
\hline & $\%$ z Płeć respondenta & $16,5 \%$ & $13,3 \%$ & $15,0 \%$ \\
\hline \multirow[t]{2}{*}{ Brak danych } & Liczebność & 27 & 10 & 37 \\
\hline & $\%$ z Płeć respondenta & $3,8 \%$ & $1,6 \%$ & $2,8 \%$ \\
\hline \multirow[t]{2}{*}{ Ogółem } & Liczebność & 707 & 622 & 1329 \\
\hline & $\%$ z Płeć respondenta & $100,0 \%$ & $100,0 \%$ & $100,0 \%$ \\
\hline
\end{tabular}

Młodzież krytycznie ocenia zaangażowanie Kościoła w odniesieniu do różnych warstw społecznych. Większa jest jeszcze grupa tych młodych, którzy sądzą, że Kościół nie udziela odpowiedzi na problemy warstw społecznych $(24,2 \%)$ lub częściowo nie udziela takich odpowiedzi (18\%), co łącznie tworzy $(42,2 \%)$ badanych. Pozytywnie zaangażowanie Kościoła w procesy odnoszące się do różnych grup społecznych ocenia $(40 \%)^{30}$.

\footnotetext{
29 Tamze, s. 474-475.

30 Tamże, s. 475.
} 


\section{ZAKOŃCZENIE}

Wydaje się, że zaznaczający się krytyczny stosunek młodzieży do społecznego zaangażowania i społecznego nauczania Kościoła wymaga pogłębionej oceny. Z pewnością puntem wyjścia jest stan świadomości młodych, ale także potrzebna jest $\mathrm{w}$ tym względzie ocena zaangażowania duszpasterskiego Kościoła w tym zakresie. Trzeba być świadomym, że część młodych ma negatywny wizerunek Kościoła. Ten stan ich świadomości może potęgować oddziaływanie mediów, które rozszerzają przekonanie, że Kościół nie realizuje konsekwentnie swojej misji. Takie nastawienie części młodych ujawniły także badania Ta sytuacja wymaga podejmowania przez Kościół działań, które uświadamiają młodym liczne obszary społecznego zaangażowania Kościoła oraz efekty jego zaangażowania. Trzeba też być świadomym, że odniesienie do Kościoła i jego nauczania jest konsekwencją budowania świadomości człowieka. Jej skutkiem bywa zagubienie człowieka we współczesności mimo aktywnego uczestnictwa w życiu społecznym, publicznym czy politycznym ${ }^{31}$.

Mimo tego stanu niezastąpiona pozostaje rola katechezy podejmującej problematykę społeczną i wychowującej do zaangażowania społecznego. Katecheza wymaga też uważnego rozpoznawania przemian dokonujących się w świadomości młodzieży. Potrzebne jest, zatem ciągłe analizowanie zmian $\mathrm{w}$ stanie świadomości młodych $\mathrm{w}$ odniesieniu do wartości. Konieczna jest także ciągła formacja katechetów i duszpasterzy ${ }^{32}$. W niej należy także podkreślić wagę nauczania zawartego w Kompendium społecznej nauki Kościoła. Wydaje się, że oprócz podręczników do nauki religii, potrzebne są obecnie też liczniejsze pomoce katechetyczne rozszerzające treści odnoszące się do społecznej nauki Kościoła w stosunku do tego zakresu, który ujmowany jest w programie katechetycznym i podręcznikach. Nauczycielowi religii trzeba dostarczyć wielu pomocy katechetycznych, które pomogą jemu w ocenie zjawisk społecznych, które szybko się dokonują i zmieniają we współczesnym świecie. Przygotowywane pomoce powinny też jemu przybliżać istotne elementy nauczania społecznego Kościoła, posługując się językiem katechezy. Takie pomoce

${ }^{31}$ Por. B. Jurczyk, Człowiek: kryzysy i nadzieja, w: Wspótczesna katecheza: kryzysy i nadzieja, red. R. Chałupniak, Opole 2010, s. 9-14.

${ }^{32}$ Por. M. Sztaba, Pedagogiczna rola katechety w kontekście idei „spoteczeństwa wychowujacego" Floriana Znanieckiego i "nauczania wychowujacego" Johanna F. Herbarta, „Katecheta” 56 (2012), nr 9, s. 5-11. 
będą ułatwiać osiąganie jednego z zasadniczych celów katechezy. Pomogą one rozwijać katechizowanym umiejętność oceniania zjawisk obecnych w życiu społecznych w świetle Ewangelii.

Ponadto, w miarę rozszerzania wśród młodych świadomości zadań chrześcijan wobec społeczeństwa, trzeba im proponować dość konkretne formy działania na rzecz społeczeństwa wypływające $\mathrm{z}$ inspiracji chrześcijańskiej. Zatem to również powinno być elementem programów duszpasterskich. Wydaje się szczególnie potrzebne, aby w działaniu duszpasterskich można było włączać ruchy i stowarzyszenia działające na danym terenie $\mathrm{w}$ różne formy zaangażowania społecznego ${ }^{33}$. Często potrzebna jest także umiejętność dostrzeżenia istniejących już form społecznej aktywności i wspólnota Kościoła powinna zapraszać młodzież do tej wspólpracy.

Promowanie wartości odnoszących się do porządku społecznego musi być ciągle poodejmowane przez media katolickie. One mogą podtrzymywać i upowszechniać społeczne nauczanie Kościoła, a zwłaszcza mogą akcentować wartości wnoszone do życia społecznego przez chrześcijan inspirowanych Ewangelią. Potrzebne jest bardzo, aby świadectwo urzeczywistniania wartości podstawowych zarówno przez pojedynczych chrześcijan jak i wspólnoty religijne było obecne również $\mathrm{w}$ mediach publicznych.

Podejmując proces katechetyczny, trzeba ciągle pamiętać o wypowiedzi papieża Benedykta XVI, który przypomniał Kościołowi, że pierwszym faktorem rozwoju społecznego jest zwiastowanie Ewangelii. Dzięki Ewangelii można wychodzić z ogniem miłości ewangelicznej do ludzi. Jeśli żyjemy prawdą ewangeliczną, możemy zaoferować pogłębione spojrzenie, które obejmuje wielkie społeczne problemy. Tylko z miłością, umocnioną przez nadzieję i rozjaśnioną przez wiarę, możliwe jest zdążać do całościowego wyzwolenia człowieka i do sprawiedliwości społecznej $j^{34}$.

33 Por. E. Verhack, Jak ewangelizować przez kształcenie w kontekście konkurencyjności, w: Wychowanie moralne w szkole katolickiej, red. A. Sowiński, A. Dymer, Szczecin 2003, s. 57-72.

${ }^{34}$ Benedykt XVI, Botschaft von Papst Benedikt XVI. An den präsidenten des päpstlichen Rats für Gerechtichkeit und Frieden alnässlich dessen Vollversammlung (nr 2 3). Watykan 2010, http://www.vatican.va/holy_father/benedict_xvi/letters/2010/documents/ hf_ben-xvi_let_20101103_giustizia-pace_ge.html (27.02.2013). 
Streszczenie. Wartości kształtujące społeczne zachowania przekazywane na katechezie. Społeczne nauczanie Kościoła wskazuje na wartości. Centralną wartością eksponowaną w tym nauczaniu jest osoba ludzka, jej prawa i relacje ze środowiskiem oraz wartość dobra wspólnego. Papieże przełomu XX i XXI wieku poświęcali tej problematyce wiele miejsca w swoim nauczaniu. Jednocześnie szybkie przemiany społeczne wymagają ciągłego odnoszenia się do nowych zjawisk społecznych z punktu wiary. Na polecenie papieża Jana Pawła II zostało opracowane i opublikowane w 2005 roku przez Papieską radę Justitia et Pax Kompendium nauki społecznej Kościoła przedstawiające w systematyczny sposób nauczanie Kościoła. Kształtowanie odniesienia wierzących do tych zjawisk stawia zadania katechezie. Katechizacja, jak podkreśla to Kompendium społecznej nauki Kościoła, ma przede wszystkim spełniać rolę formacyjną. To nauczanie Kościoła jest obecne w nauczaniu na lekcjach religii w Polsce i kształtuje wrażliwość młodych na te wartości. Tę wrażliwość ujawniają również badania odnoszenia się młodzieży do wartości społecznych. Wyniki tych badań uświadamiają również duszpasterzom i nauczycielom religii konieczność podejmowania działań dydaktycznych i formacyjnych pogłębiających formację społeczną wiernych i zaangażowanie w sprawy społeczne ważne dla ludzi obecnej doby.

Słowa kluczowe: wartości; katecheza; wychowanie; katolicka nauka społeczna.

Abstract. The values forming social behavior taught during Catechesis. Social teaching of the Church indicates the values. The central value exposed in the teaching is the human person, its rights and relationship with the community and the value of the common good. The Popes of the turn of XX and XXI century devoted a lot of space in their teaching to this subject. At the same time rapid changes in human society require continuous reference to new social phenomena in terms of faith. In 2005 at the command of Pope John Paul II the Compendium of the Social Doctrine of the Church, which shows the Church's teaching in a systematic way, was developed and published by the Pontifical council. It makes catechesis (religious instruction lessons) responsible for the formation of believers attitude to these phenomena. Catechesis, as the Compendium of the Social Doctrine of the Church emphasizes, is meant to serve a formation role. This teaching of the Church is present in the classroom teaching of religion in Poland and shapes sensitivity of young people to these values. This study also reveals the sensitivity of adolescents who refer to social values. The results of these studies also show the pastors and religious educators the need to take action in the field of teaching and formation which may extend the social formation of believers and their involvement in social issues important to the people of the present time.

Keywords: values; catechesis; education; the Social Doctrine of the Church. 